\title{
Desulfovibrio profundus sp. nov., a Novel Barophilic Sulfate-Reducing Bacterium from Deep Sediment Layers in the Japan Sea
}

\author{
S. J. BALE, ${ }^{1}$ K. GOODMAN,${ }^{1}$ P. A. ROCHELLE, ${ }^{2}$ J. R. MARCHESI, ${ }^{2}$ J. C. FRY, ${ }^{2}$ \\ A. J. WEIGHTMAN, ${ }^{2}$ AND R. J. PARKES ${ }^{1 *}$ \\ Department of Geology, University of Bristol, Bristol BS8 IRJ, ${ }^{1}$ and School of Pure and \\ Applied Biology, University of Wales, Cardiff, Cardiff CF1 $3 T L,{ }^{2}$ United Kingdom
}

\begin{abstract}
Several strains of a strictly anaerobic, vibrio-shaped or sigmoid, sulfate-reducing bacterium were isolated from deep marine sediments (depth, 80 and $500 \mathrm{~m}$ ) obtained from the Japan Sea (Ocean Drilling Program Leg 128, site 798B). This bacterium was identified as a member of the genus Desulfovibrio on the basis of the presence of desulfoviridin and characteristic phospholipid fatty acids (iso 17:1 7 and iso 15:0), the small number of growth substrates utilized (lactate, pyruvate, and hydrogen), and 16S rRNA gene sequence analysis data. Based on data for $16 \mathrm{~S}$ rRNA sequences $(1,369 \mathrm{bp})$, all of the Japan Sea strains were identical to each other and were most closely related to Desulfovibrio salexigens and less closely related to Desulfovibrio desulfuricans (levels of similarity, 91 and $\mathbf{8 9 . 6 \%}$, respectively). There were, however, considerable phenotypic differences (in temperatures, pressures, and salinities tolerated, growth substrates, and electron donors) between the Japan Sea isolates and the type strains of previously described desulfovibrios, as well as important differences among the Japan Sea isolates. The Japan Sea isolates were active (with sulfide production) over a wide temperature range $\left(15\right.$ to $65^{\circ} \mathrm{C}$ ) and a wide sodium chloride concentration range $(0.2$ to $10 \%)$ (moderate halophile), and they were barophiles that were active at pressures up to about $40 \mathrm{MPa}$ (400 atm). The optimum pressures for activity corresponded to the calculated pressures at the depths from which the organisms were isolated (for isolates obtained at depths of 80 and $500 \mathrm{~m}$ the optimum activities occurred at 10 and $15 \mathrm{MPa}$, respectively [100 and $150 \mathrm{~atm}$, respectively]). This confirms that the organisms came from deep sediments and indicates that they are well-adapted for deep sediment conditions, which is consistent with other characteristics (utilization of hydrogen, fermentation, and utilization of ferric iron and organic sulfonates as electron acceptors). We propose that Japan Sea isolate 500-1 is the type strain of a new species, Desulfovibrio profundus.
\end{abstract}

Bacterial sulfate reduction is the dominant anaerobic terminal oxidation process in marine sediments, and in coastal sediments this process can be responsible for more than $50 \%$ of the organic matter degradation (21). The importance of sulfate reduction decreases in deeper-water sediments, where the diagenetic zones are greatly extended $(16,22)$, and as a result sulfate can be present to a depth of several hundred meters in some pelagic sediments (4). Thus, there is the potential for active sulfate reduction to continue at great depth within marine sediments. Recently, this was demonstrated for Japan Sea sediments, where sulfate reduction was shown to be present to a depth of at least $425 \mathrm{~m}$ together with significant bacterial populations (30). Viable sulfate-reducing bacteria were also present to a depth of $80 \mathrm{~m}$, and other viable bacterial types were present at even greater depths. These findings significantly extend the environment for sulfate-reducing bacteria and are consistent with reports of sulfate reduction in other deep environments, such as oil reservoirs $(7,41)$, deep aquifers (20), and groundwaters (33).

Since readily degradable organic matter is rapidly removed in near-surface sediments (32) and since porosity decreases and temperature and pressure increase with sediment depth, it appears that sulfate-reducing bacteria that are able to survive in deep marine sediments must be well-adapted to this hostile environment. Deep marine sediments thus may be an important source of unique bacteria, which may have environmental and biotechnological significance. In this paper we describe the characteristics of sulfate-reducing bacteria isolated from deep marine sediments from the Japan Sea.

\footnotetext{
${ }^{*}$ Corresponding author.
}

\section{MATERIALS AND METHODS}

Sample collection. Sediment samples were collected from Ocean Drilling Program Site 798B in the Japan Sea (water depth, $900 \mathrm{~m}$ ). The deepest sediment obtained was sediment from $518 \mathrm{~m}$ below the seafloor. Whole round core samples were cut from intact cores under sterile anaerobic conditions (9) and were transported anaerobically $(8)$ at $4^{\circ} \mathrm{C}$ back to a laboratory for analysis a few weeks later. Full details concerning the subsequent handling of the samples have been published elsewhere $(9,31)$. Briefly, 5 -ml subcores were removed under sterile anaerobic conditions from the centers of whole round cores and serially diluted prior to injection into most-probable-number (MPN) vials containing modified Postgate's sulfate-reducing bacterial medium supplemented with either acetate or lactate and adjusted to in situ levels of salinity. The medium contained (per liter) $0.5 \mathrm{~g}$ of $\mathrm{KH}_{2} \mathrm{PO}_{4}, 1.0 \mathrm{~g}$ of $\mathrm{NH}_{4} \mathrm{Cl}, 1.0 \mathrm{~g}$ of $\mathrm{CaSO}_{4}, 5.0 \mathrm{~g}$ of $\mathrm{MgSO}_{4} \cdot 7 \mathrm{H}_{2} \mathrm{O}$, $3.5 \mathrm{~g}$ of sodium lactate $(70 \%$ [ $\mathrm{vol} / \mathrm{vol}$ ] solution) or $1.8 \mathrm{~g}$ of sodium acetate (anhydrous), $1.0 \mathrm{~g}$ of yeast extract, $0.1 \mathrm{~g}$ of ascorbic acid, $0.1 \mathrm{~g}$ of thioglycolic acid, $0.5 \mathrm{~g}$ of $\mathrm{FeSO}_{4} \cdot 7 \mathrm{H}_{2} \mathrm{O}, 32.0 \mathrm{~g}$ of $\mathrm{NaCl}, 5.0 \mathrm{~g}$ of $\mathrm{MgCl}_{2} \cdot 6 \mathrm{H}_{2} \mathrm{O}$, and $1.0 \mathrm{ml}$ of resazurin $(0.1 \%)$. The $\mathrm{pH}$ was adjusted to 7.2 , and the medium was autoclaved at $121^{\circ} \mathrm{C}$ and then cooled under $90 \% \mathrm{~N}_{2}-10 \% \mathrm{CO}_{2}$. When the medium was cool, $30 \mathrm{ml}$ of a $1 \mathrm{M}$ bicarbonate solution was added, the $\mathrm{pH}$ was adjusted to 7.5 with $\mathrm{Na}_{2} \mathrm{CO}_{3}-\mathrm{HCl}$, and the medium was dispensed under $\mathrm{N}_{2}-\mathrm{CO}_{2}$ into sterile, evacuated, $7-\mathrm{ml}$, crimp top vials with butyl septa. The vials were incubated at $16^{\circ} \mathrm{C}$ the mean temperature of the core from the sediment surface to a depth of $518 \mathrm{~m}$ Enrichment and isolation of pure cultures. To increase growth rates, the incubation temperature for subcultures obtained from positive MPN vials was increased to $25^{\circ} \mathrm{C}$. Once stable enrichment cultures had been established from samples obtained from $2,10,80$, and $500 \mathrm{~m}$ below the seafloor, subsequent enrichment cultures were grown in both Postgate's medium and the betterdefined Widdel's medium (46) (with $\mathrm{NaCl}$ and $\mathrm{MgCl}_{2} \cdot 6 \mathrm{H}_{2} \mathrm{O}$ concentrations adjusted as described above). These cultures were inoculated into agar shake dilution series containing different growth substrates (31), and when individual black colonies developed, they were inoculated into liquid Widdel's medium containing the same substrate. This process was repeated until pure cultures were obtained. Purity was assessed by observing a uniform cell type, Gram staining, a lack of aerobic growth, and a lack of growth on a range of complex substrates under anaerobic conditions and by analyzing 16S rRNA gene libraries from putative pure cultures.

Physiological characterization. The characteristics of Japan Sea isolates were compared with the characteristics of the type strains of Desulfovibrio desulfuricans (DSM 642) and Desulfovibrio salexigens (DSM 2638) obtained from the Deutsche Sammlung von Mikroorganismen und Zellkulturen, Braunschweig, 
TABLE 1. Growth substrates and electron acceptors utilized by Japan Sea isolates and the type strains of previously described Desulfovibrio species

\begin{tabular}{|c|c|c|c|c|}
\hline Characteristic & $\begin{array}{c}\text { Japan Sea } \\
\text { strain } \\
80-55\end{array}$ & $\begin{array}{c}\text { Japan Sea } \\
\text { strain } \\
500-1^{\mathrm{T}}\end{array}$ & $\begin{array}{l}\text { D. salex- } \\
\text { igens } \\
\text { DSM } 2638^{\mathrm{T}}\end{array}$ & $\begin{array}{l}\text { D. desul- } \\
\text { furicans } \\
\text { DSM } 642^{\mathrm{T}}\end{array}$ \\
\hline \multicolumn{5}{|l|}{ Substrate utilization $^{a}$} \\
\hline Lactate & $+^{b}$ & + & + & + \\
\hline Acetate & - & $+^{c}$ & - & - \\
\hline Propionate & - & - & - & - \\
\hline Ethanol & - & - & + & + \\
\hline Benzoate & - & - & - & - \\
\hline Pyruvate & + & + & + & + \\
\hline Choline & - & - & $(+)$ & + \\
\hline Formate & - & - & + & + \\
\hline Fructose & - & - & + & - \\
\hline Fumarate & - & - & - & + \\
\hline $\begin{array}{l}\text { Hydrogen (auto- } \\
\text { trophic) }\end{array}$ & $(+)$ & $(+)$ & - & - \\
\hline $\begin{array}{l}\text { Hydrogen (mixo- } \\
\text { trophic) }\end{array}$ & + & + & + & + \\
\hline Isobutyrate & - & - & - & - \\
\hline Malate & - & - & + & + \\
\hline Stearate & - & - & - & - \\
\hline Palmitate & - & - & - & - \\
\hline Alanine & - & - & + & - \\
\hline Glutamate & - & - & - & - \\
\hline Glycine & - & - & - & - \\
\hline Cysteine & - & - & - & - \\
\hline Serine & - & - & + & - \\
\hline Toluene & $(+)$ & $(+)$ & - & - \\
\hline Phenol & - & - & - & - \\
\hline Hexadecane & - & - & - & - \\
\hline \multicolumn{5}{|l|}{ Fermentation } \\
\hline Choline & - & - & - & $(+)$ \\
\hline Pyruvate & + & + & - & - \\
\hline Lactate & + & + & - & - \\
\hline \multicolumn{5}{|l|}{$\begin{array}{l}\text { Electron acceptor } \\
\text { utilization }\end{array}$} \\
\hline Sulfate & + & + & + & + \\
\hline Sulfite & + & + & + & + \\
\hline Sulfur & - & - & - & - \\
\hline Thiosulfate & - & + & + & + \\
\hline $\mathrm{Fe}(\mathrm{III})$ & + & + & ND & + \\
\hline Nitrate & + & + & + & + \\
\hline Fumarate & $(+)$ & $(+)$ & $(+)$ & $(+)$ \\
\hline Lignosulfonate & + & + & - & - \\
\hline Dimethyl sulfoxide & + & - & + & - \\
\hline
\end{tabular}

${ }^{a}$ Electron donors utilized when sulfate was the electron acceptor.

${ }^{b}+$, utilized; - , not utilized; $(+)$, poor utilization (less than $1 \mathrm{mM}$ sulfide is produced); ND, not determined.

${ }^{c}$ Growth on solid medium only.

${ }^{d}$ Electron acceptors utilized when lactate was the electron donor.

Germany. The type strains were grown in the media recommended by the Deutsche Sammlung von Mikroorganismen und Zellkulturen. All cultures were routinely incubated in Widdel's medium at $25^{\circ} \mathrm{C}$ and $0.1 \mathrm{MPa}(1 \mathrm{~atm})$. As growth in this medium was accompanied by production of an iron sulfide precipitate and bacterial clumping, particularly at elevated pressures, absorbance could not reliably be used to measure growth, and sulfide production was used instead (6) Sulfide production correlated with both sulfate removal $(P<0.001)$ and bacterial concentrations determined microscopically $(P=0.01)$. When using sulfide production as an index of growth was not appropriate (e.g., in fermentation tests), microscopy and substrate removal or formation of metabolic products were used to determine growth.

Substrate and electron acceptor utilization. Metabolic tests were conducted in 35-ml serum bottles sealed with butyl rubber stoppers (Phase Separations, Deeside, United Kingdom) by using a $1.5 \%$ inoculum. Details concerning the various electron acceptors and donors and the concentrations used are listed in Table 1 Unless specified otherwise, growth was determined in the presence of $20 \mathrm{mM}$ sulfate. Growth was determined after at least 21 days of incubation, although in some instances incubation times of up to 6 months were required before growth was detectable (e.g., when lignosulfonate and dimethyl sulfoxide were used)

Temperature. Cultures were incubated at temperatures ranging from 7 to $70^{\circ} \mathrm{C}$. Incubation was continued for 56 days, but whenever growth occurred, visible turbidity was detected within 21 days.

Pressure. Incubation experiments at elevated pressures were conducted by using a purpose-built pressure vessel (31). All headspace gas from inoculated cultures was removed and replaced with culture medium. As cultures could not be observed during incubation under pressure, incubation times were estimated by adding $48 \mathrm{~h}$ to the incubation times necessary for the development of visible turbidity in control cultures incubated at atmospheric pressure. The incubation times were generally between 10 and 12 days. Sulfide concentrations were determined immediately following depressurization and were expressed as percent ages of the sulfide concentrations obtained with 1-atm controls.

Sodium chloride and $\mathbf{p H}$ ranges for growth. Media containing $\mathrm{NaCl}$ at concentrations ranging from 0 to $14 \%$ were prepared by adding different volumes of a sterile stock solution of $\mathrm{NaCl}(35 \%)$ to $\mathrm{NaCl}$-free medium. Media with $\mathrm{pH}$ values ranging from 3.5 to 9 were prepared as described by Widdel and Bak (46)

Hibitane resistance. Resistance to hibitane, a known characteristic of $D$. salexigens (40), was determined by incubating cultures in standard growth medium containing hibitane at concentrations ranging from 0.01 to $1 \mathrm{~g} /$ liter.

Substrate removal and fermentation products. Volatile fatty acid concentrations in culture media were determined by ion exclusion chromatography ( $\mathrm{Di}$ onex, Sunnyvale, Calif.) as described by Wellsbury et al. (45). Samples were removed anaerobically from growing cultures and were filtered through a 0.1 $\mu m$-pore-size Anotop filter (Whatman, Maidstone, United Kingdom) prior to analysis.

Desulfoviridin. The presence of bisulfite reductase (desulfoviridin) was determined by adding $\mathrm{NaOH}$ to a resuspended pellet of cells and viewing the preparation under UV light as described by Postgate (35).

DNA base composition. DNA was extracted and purified by the method of Ausubel et al. (1). The $\mathrm{G}+\mathrm{C}$ content was determined by the method of Tamaoka and Komagata (42). DNA was treated with P1 nuclease and alkaline phosphatase, and the nucleosides were separated by high-performance liquid chromatography by using a model System Gold apparatus (Beckman) equipped with an Ultrasphere $\mathrm{C}_{18}$ column (Beckman). DNAs from the following three bacteria were used as standards: Clostridium perfringens, Escherichia coli B, and Micrococcus luteus (Micrococcus lysodeikticus).

Whole-cell protein profiles. Total cellular proteins were extracted from $10-\mathrm{ml}$ portions of pure cultures grown in Widdel's medium. A pellet of each pure culture was resuspended in $200 \mu \mathrm{l}$ of sterile $\mathrm{H}_{2} \mathrm{O}, 225 \mu \mathrm{l}$ of sample buffer $(0.125$ M Tris- $\mathrm{HCl}[\mathrm{pH} 6.8], 20 \%$ glycerol, $4 \%$ sodium dodecyl sulfate, $0.05 \%$ bromophenol blue) was added, and then $25 \mu$ l of $14.3 \mathrm{M}$ mercaptoethanol was added. The preparations were incubated at $100^{\circ} \mathrm{C}$ for $5 \mathrm{~min}$, centrifuged at $15,000 \times g$ for $5 \mathrm{~min}$, and stored at $-20^{\circ} \mathrm{C}$ until they were needed. Proteins were separated by sodium dodecyl sulfate-polyacrylamide gel electrophoresis essentially as described by Laemmli (24). Electrophoresis was performed with a stacking gel containing $4 \%$ polyacrylamide and a resolving gel containing $12 \%$ polyacrylamide. Each gel was silver stained by using a modified method of Morrissey (28)

Ribotyping and hybridization. Genomic DNAs were isolated from strains 80-55 and 500-1 $1^{\mathrm{T}}(\mathrm{T}=$ type strain) by the method of Ausubel et al. (1) and were digested with restriction endonucleases EcoRI and Pst as recommended by the manufacturer (Boehringer Mannheim). DNA fragments were separated by electrophoresis on $0.7 \%$ agarose gels with Tris-borate-EDTA buffer at $10 \mathrm{~V} \mathrm{~cm}^{-}$ (39), transferred to an $\mathrm{N}^{+}$nylon membrane (Boehringer Mannheim) by the Southern method (39), and fixed with UV light. Hybridization to the 16S rRNA gene was performed with a fluorescein-labelled eubacterium-specific oligonucleotide probe (EUB338; 5'-GCT GCC TCC CGT AGG AGT-3') at $46^{\circ} \mathrm{C}$, and the preparation was washed at $48^{\circ} \mathrm{C}$ as recommended by the manufacturer. Chemiluminescence was detected at room temperature by using the instructions of the manufacturer (Boehringer Mannheim). The probe was visualized after detection by exposing the membrane to Kodak X-OMAT X-ray photographic film and developing the film as recommended by the manufacturer (Eastman Kodak).

$16 S$ rRNA gene sequence analysis. DNA was extracted by standard procedures (39), and 16S rRNA gene sequences were amplified by the PCR as described previously $(37,38)$. The PCR primers used for $16 \mathrm{~S}$ rRNA gene amplification were based on the primers described by Lane (25), with slight modifications; the primers used were primers 27F (5'-GTG CTG CAG AGA GTT TGA TCC TGG CTC AG-3'), 1392R (5'-CAC GGA TCC ACG GGC GGT GTG TRC-3'), and 1492R ( $5^{\prime}$-CAC GGA TCC TAC GGG TAC CTT GTT ACG ACT T-3') (the numbers in the designations are the positions in the $E$. coli $16 \mathrm{~S}$ rRNA sequence to which the $3^{\prime}$ end of the primer annealed). The primers were designated by using the convention of Lane (25). Amplified 16S rRNA gene products were ligated into vector pCRII and used to transform $E$. coli INV $\alpha F^{\prime}$ with a TA cloning kit (Invitrogen) as recommended by the manufacturer. Cloned $16 \mathrm{~S}$ rRNA genes were screened by performing a restriction fragment length polymorphism analysis of the whole plasmid plus the 16S rRNA insert and by DNA sequencing with an ALF sequencer (Pharmacia), as described previously (37, 38 ). The complete 16S rRNA gene sequence between positions 27 and 1392 ( $E$. coli numbering) was obtained by connecting overlapping shorter sequences with the DNASIS suite of programs (Hitachi). Sequences were aligned for the phylogenetic analysis with the Clustal V program (18). Additional analyses were 


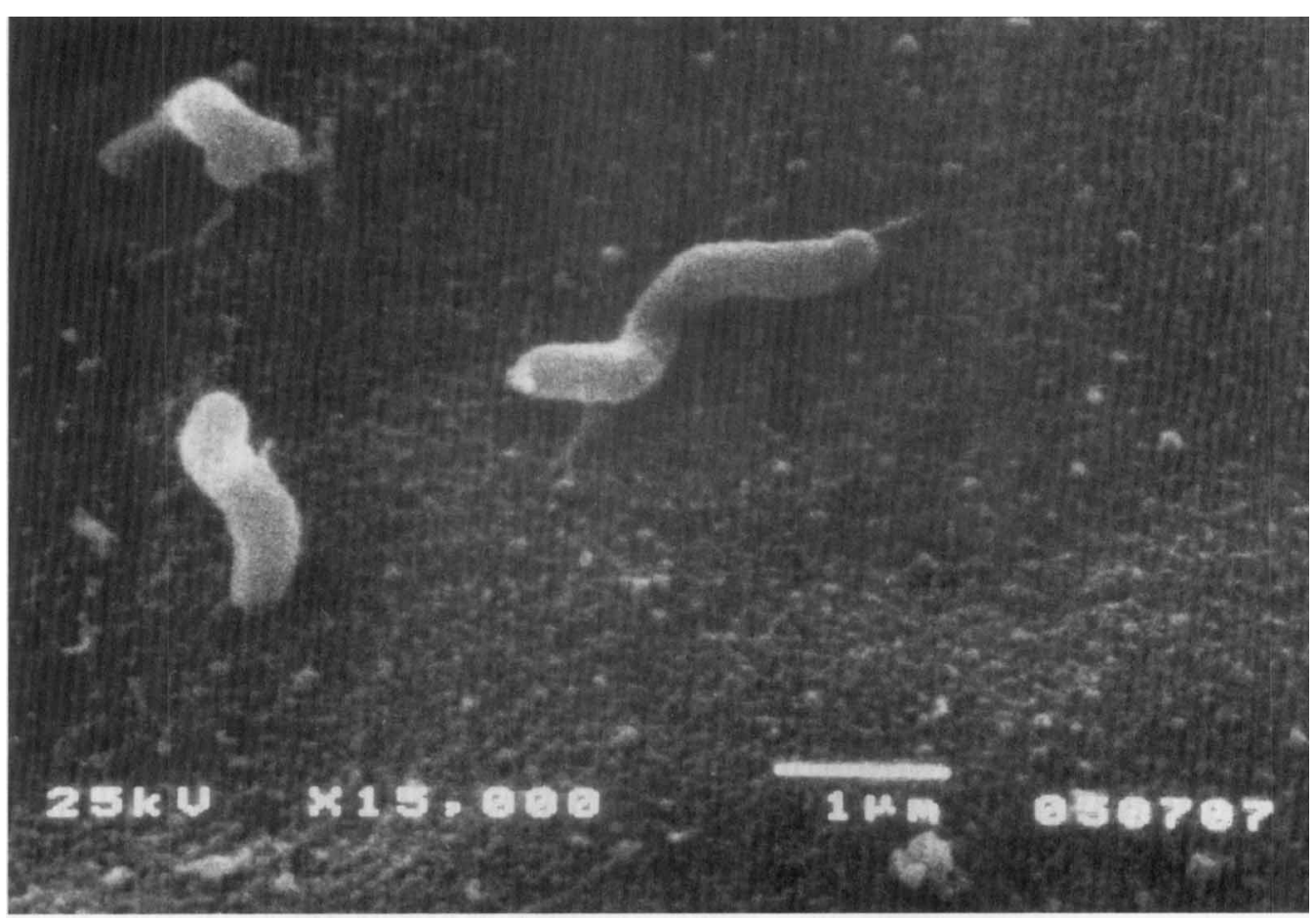

FIG. 1. Scanning electron micrograph of D. profundus $500-1^{\mathrm{T}}$

performed with the PHYLIP suite of programs (15) by using data and services provided by the Ribosomal Database Project (University of Illinois, UrbanaChampaign) (26) and the Antwerp Database (29). A phylogenetic tree was constructed by using TREECON software (44).

Phospholipid fatty acid (PLFA) analysis. Freeze-dried bacterial cells were extracted by using a modified Bligh-Dyer monophasic solvent system with phosphate buffer $(2,17)$. Phospholipids were isolated from the total lipid extracts by column chromatography (aminopropylphase bonded silica cartridges) and were released as the methyl esters after mild alkaline methanolysis (17) prior to identification by gas chromatography and gas chromatography-mass spectrometry. Positions of unsaturation were determined by the formation of dimethyl disulfide adducts (47).

Nucleotide sequence accession number. The 16S rRNA gene sequence of Desulfovibrio profundus sp. nov. has been deposited in the GenBank database under accession number U90726.

\section{RESULTS}

Enrichment and isolation. Enrichment in Postgate's medium required long incubation times (in some cases more than 9 months) in order to obtain stable, sulfide-producing cultures. An unavoidable 18-month delay between inoculation of the initial MPN vials and subsequent processing may have contributed to this. Cultures were obtained from the 2-, 10-, 80-, and $500-\mathrm{m}$ samples, and these cultures grew on a range of substrates in agar shake preparations (31), although long incubation times (3 to 4 months) were required for some substrates (particularly palmitate, fructose, and benzoate; there was also variation in incubation times with sample depth). Initially, however, growth of colonies from agar shake preparations was obtained only from the 80 -m sample grown on liquid medium with lactate; five similar isolates were obtained, and two of these, strains 80-55 and 80-94, were studied further. An isolate from the $500-\mathrm{m}$ sample, strain $500-1^{\mathrm{T}}$, was finally obtained on an acetate agar plate, although this organism did not grow in liquid acetate medium and growth in liquid culture was continued with lactate. While initial enrichment cultures required at least 6 weeks of incubation before growth was detectable, later enrichment cultures, and eventually pure cultures, pro- duced significant amounts of sulfide within 2 weeks after inoculation into lactate medium.

Cell morphology. The Japan Sea isolates were motile, gramnegative, vibrio-shaped or sigmoid cells $(0.5$ to 1 by 1 to $2 \mu \mathrm{m})$ (Fig. 1) with some pleomorphism.

Below the Japan Sea isolates are compared with $D$. salexigens and $D$. desulfuricans, as the initial 16S rRNA gene sequence analysis revealed that these sulfate-reducing bacteria are closely related.

Ranges and optimum conditions for activity. Based on sulfide production, Japan Sea strains $80-55$ and $500-1^{\mathrm{T}}$ were active at temperatures between 15 and $65^{\circ} \mathrm{C}$, and optimum activity occurred at temperatures around $25^{\circ} \mathrm{C}$ (Fig. 2). The activity temperature profile of these organisms was unusual, with considerable reproducible activity at the extremes of the temperature range tested $(60 \%$ of the sulfide production at the optimum temperature). This was significantly different $(P \ll$

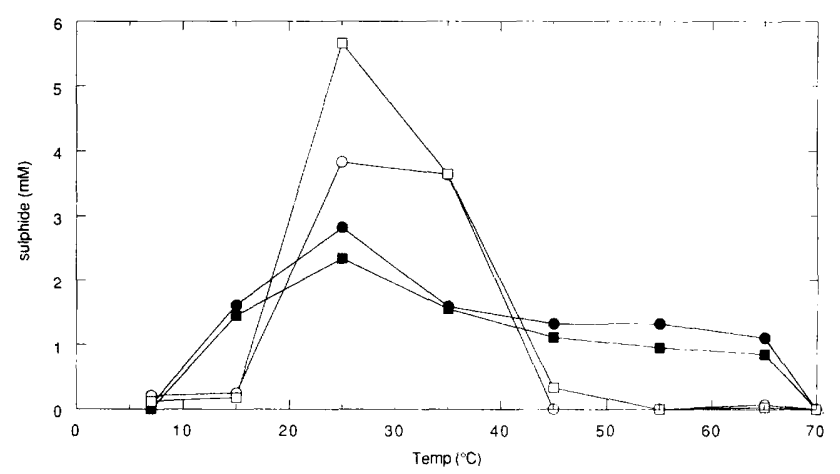

FIG. 2. Temperature characteristics of Japan Sea isolates and the type strains of previously described desulfovibrios. Symbols: $\mathbf{Q}$, strain $80-55 ; \square$, strain $500-1^{\mathrm{T}}$, $\bigcirc, D$. desulfuricans; $\square, D$. salexigens. 


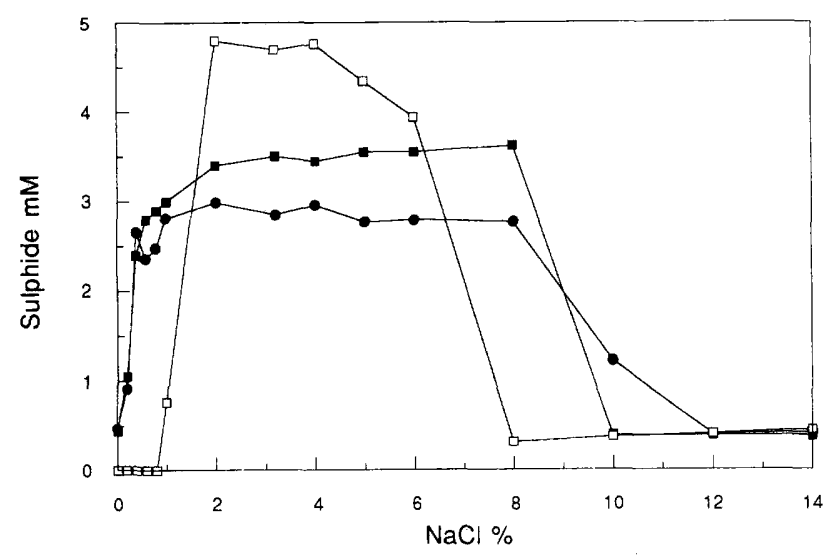

FIG. 3. Salinity characteristics of Japan Sea isolates and the type strain of a previously described desulfovibrio. Symbols: 9 , strain $80-55$; $\mathbf{E}$, strain $500-1^{\mathrm{T}} ; \square$, D. salexigens.

0.001 ) than the temperature characteristics of $D$. salexigens and $D$. desulfuricans incubated under identical conditions, which had a distinct activity optimum at temperatures around 30 to $36^{\circ} \mathrm{C}$ and a maximum temperature for activity of around $40^{\circ} \mathrm{C}$ (Fig. 2). Sulfide production occurred at $\mathrm{pH}$ values between 4.5 and 9, and the optimum $\mathrm{pH}$ was about 7. The Japan Sea strains were moderate halophiles; they were active in the presence of 0.6 to about $10 \% \mathrm{NaCl}$ (Fig. 3), in contrast to the slightly halophilic organism $D$. salexigens, which required at least $2 \%$ $\mathrm{NaCl}$ for sulfide production and was not active at $\mathrm{NaCl}$ concentrations above about $6 \%$.

Based on sulfide production, Japan Sea strains 80-55 and 500$1^{\mathrm{T}}$ were more active at an elevated pressure than at $0.1 \mathrm{MPa}(1$ atm), and the maximum pressure for activity was ca. $40 \mathrm{MPa}$ $(400 \mathrm{~atm})$ (Fig. 4). Strains $80-55$ and $500-1^{\mathrm{T}}$ had distinctly different pressure optima (10 and $15 \mathrm{MPa}$, respectively [100 and 150 atm, respectively]). In contrast, $D$. salexigens and $D$. desulfuricans were active at pressures up to ca. 5 and $15 \mathrm{MPa}$, respectively (50 and $150 \mathrm{~atm}$, respectively). The maximum sulfide production by the Japan Sea strains at elevated pressures was significantly greater $(P<0.02)$ than the maximum sulfide production by the other desulfovibrios tested. Limited direct microscopic

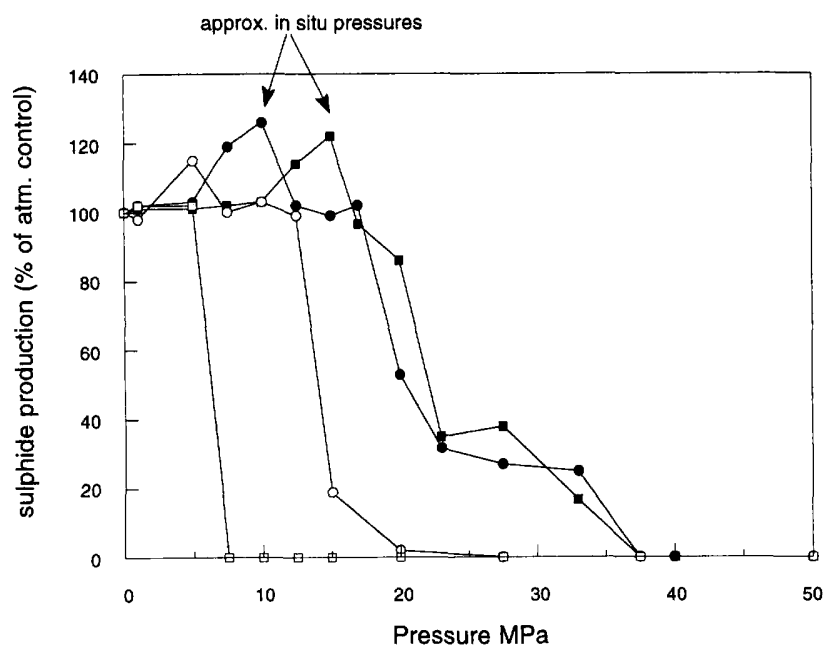

FIG. 4. Pressure characteristics of Japan Sea isolates and the type strains of previously described desulfovibrios. Symbols: $\mathbf{Q}$, strain $80-55$; $\mathbf{\square}$, strain $500-1^{\mathrm{T}}$; O, D. desulfuricans; $\square, D$. salexigens. observations of samples incubated under elevated pressures confirmed that the Japan Sea strains grew better under elevated pressures than at $0.1 \mathrm{MPa}(1 \mathrm{~atm})$, in contrast to $D$. salexigens.

Unlike $D$. salexigens, neither of the Japan Sea strains could grow in the presence of $1 \mathrm{~g}$ of hibitane per liter, and these organisms were inhibited by hibitane concentrations as low as $0.1 \mathrm{~g} /$ liter.

Biochemical characteristics. Strains $80-55$ and $500-1^{\mathrm{T}}$ both produced characteristic fluorescence under UV illumination, indicating that desulfoviridin was present. The PLFA profiles of these two strains were similar to each other and to the PLFA profiles of $D$. salexigens and $D$. desulfuricans. The PLFA profiles of all of these organisms were dominated by saturated and monounsaturated $\mathrm{C}_{16}$ and $\mathrm{C}_{18}$ fatty acids and contained branched fatty acids characteristic of desulfovibrios (iso 17:1 $1 \omega 7$ and iso 15:0) $(14,43)$. The protein profiles of strains $80-55$ and $500-1^{\mathrm{T}}$ were identical, but distinct from the protein profiles of $D$. salexigens and $D$. desulfuricans (data not shown).

The $\mathrm{G}+\mathrm{C}$ content of strain $500-1^{\mathrm{T}}$ was estimated to be 53 mol\%; this compares with previously reported values of 49 and $59 \mathrm{~mol} \% \mathrm{G}+\mathrm{C}$ for $D$. salexigens and $D$. desulfuricans, respectively (13). When genomic DNAs from strains 80-55 and $500-1^{\mathrm{T}}$ were separately digested with EcoRI and Pst I and hybridized with eubacterium-specific $16 \mathrm{~S}$ ribosomal DNA probe EUB338, both organisms produced the same band patterns, indicating that they had identical ribotypes.

Growth substrates and electron acceptors. Growth substrate and electron acceptor data for the Japan Sea strains, $D$. salexigens, and $D$. desulfuricans are shown in Table 1. Compared with other desulfovibrios, the Japan Sea strains used a relatively limited number of growth substrates during sulfate reduction (46) (Table 1); both lactate and pyruvate were incompletely oxidized to acetate, and hydrogen was utilized. Lactate and pyruvate were also fermented by the Japan Sea strains, but not by $D$. salexigens and $D$. desulfuricans. In contrast to both $D$. salexigens and $D$. desulfuricans, both Japan Sea strains were capable of weak growth on hydrogen in the absence of acetate as a carbon source. Sulfate, sulfite, thiosulfate (only strain $500-1^{\mathrm{T}}$ ), iron oxyhydroxide, nitrate, dimethyl sulfoxide (only strain 80-55), and lignosulfonate were used as electron acceptors. Overall, the metabolic capabilities of the two Japan Sea strains were similar but not identical and were substantially different from the metabolic capabilities of both $D$. salexigens and $D$. desulfuricans.

Molecular analysis of pure cultures obtained from Japan Sea sediment. DNAs were extracted from all six Japan Sea isolates, and small 16S rRNA gene libraries were prepared. Selected clones ( 5 to 12 clones from each library) were compared and were shown to produce identical 16S ribosomal DNA restriction fragment length polymorphism profiles with restriction endonucleases Eco RI, AvaII, and TaqI. The results of a partial sequence analysis of a subset of the clones obtained from the sulfate-reducing bacterial cultures were consistent with the purity established previously by microscopy and growth checks and also suggested that the isolates in the different cultures were members of the same species.

Phylogenetic analysis of sulfate-reducing bacterial strains isolated from Japan Sea sediments based on 16S rRNA gene sequences. 16S rRNA genes from sulfate-reducing bacterial strains $80-55$ and $500-1^{\mathrm{T}}$ were sequenced over almost their entire length $(1,369 \mathrm{bp})$ and were found to be identical. The sequences obtained was compared with the sequences of other sulfate-reducing bacteria, and this comparison revealed that strains $80-55$ and $500-1^{\mathrm{T}}$ were most closely related to $D$. salexigens and less closely related to $D$. desulfuricans (levels of sequence similarity for the $1,369 \mathrm{bp}, 91.0$ and $89.6 \%$, respectively). Figure 5 shows a dendrogram based on a phylogenetic 


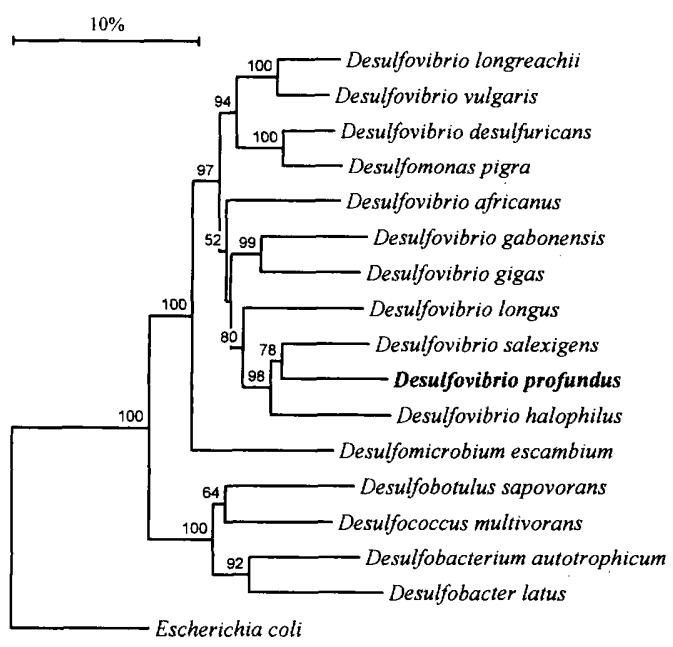

FIG. 5. Phylogenetic relationships based on 16S rRNA gene sequences, showing the position of $D$. profundus with respect to other sulfate-reducing bacteria belonging to the delta subclass of the Proteobacteria. The tree was constructed by the neighbor-joining method from a similarity matrix based on the Jukes-Cantor algorithm and was rooted by using $E$. coli as an outgroup. Scale bar $=10 \%$ sequence similarity. Most of the reference sulfate-reducing bacterial sequences were obtained from the Ribosomal Database Project (26); the only exceptions were the $D$. gabonensis and $D$. halophilus sequences, which were obtained from GenBank (accession numbers U31080 and U48243, respectively). Base positions 29 to 1357 (numbering based on the $E$. coli $16 \mathrm{~S}$ rRNA gene [25]) were included in the analysis. The numbers at the branch points are bootstrap values, which derived from 500 analyses.

analysis in which the $16 \mathrm{~S}$ rRNA gene sequence obtained from strains $80-55$ and $500-1^{\mathrm{T}}$ was compared with the sequences of other Desulfovibrio species and other sulfate-reducing bacterial species belonging to the $\delta$ subclass of the Proteobacteria (13). This tree includes the moderately halophilic organisms Desulfovibrio halophilus (4) and Desulfovibrio gabonensis (42). Although neither of the latter species is more closely related to strains $80-55$ and $500-1^{\mathrm{T}}$ than $D$. salexigens is, D. halophilus does cluster in the same group (Fig. 5).

Trees constructed by using distance, maximum-parsimony, and maximum-likelihood methods gave identical topologies and assignments of the $80-55$ and $500-1^{\mathrm{T}}$ 16S rRNA gene sequences.

\section{DISCUSSION}

The recent demonstration of a deep bacterial biosphere which is widespread in marine sediments to depths of more than $500 \mathrm{~m}$ below the seafloor $(10-12,30,31)$ not only has confirmed geochemical evidence for deep bacterial activity (4, 5,23 ) but also has raised questions about what types of bacteria are present and how they survive at such depths and in sediments deposited more than $10 \times 10^{6}$ years ago. Initial estimates indicate that the global bacterial biomass in marine sediments is equivalent to $10 \%$ of the carbon in the surface biosphere (30), and hence deep marine sediments represent a newly discovered bacterial environment with potentially unique diversity, including tolerance to elevated temperatures and pressures, which increase during burial. Sulfate-reducing bacteria have been found previously in deep marine deposits; for example, Morita and Zobell (27) described sparse and sporadic occurrence of such organisms down to a depth of $8 \mathrm{~m}$. However, as near-surface sediments contain high bacterial populations $(3,36)$, bacteria obtained from deep sediments have usually been considered contaminants from surface layers or reactivated dormant bacteria (49). In addition, previously there has been no physiological evidence that bacteria obtained from deep sediments were adapted to deep conditions to support a deep sediment origin for these organisms.

In the Japan Sea sediments the presence of deep bacterial populations and activity was confirmed by a range of independent methods $(9,30)$, and viable counts of sulfate-reducing bacteria correlated with sulfate reduction rates, changes in pore water sulfate content, and concentrations of reduced sulfur species. Sulfate-reducing bacterial strains $80-55$ and $500-1^{\mathrm{T}}$ were isolated from the original MPN vials inoculated with sediment obtained from 80 and $500 \mathrm{~m}$ below the seafloor, respectively. These isolates are gram-negative, desulfoviridinpositive, sulfate-reducing bacteria which incompletely oxidize lactate and pyruvate. This, together with the presence of PLFA characteristic of desulfovibrios (14), places them in the Desulfovibrio group. This was confirmed by $16 \mathrm{~S}$ rRNA gene sequence analysis data, which also indicate that these bacteria are closely related, but not identical, to $D$. salexigens and $D$. desulfuricans (levels of sequence similarity, 91.0 and $89.6 \%$, respectively) (Fig. 5).

The growth substrates utilized by Japan Sea sulfate-reducing bacterial strains $80-55$ and $500-1^{\mathrm{T}}$ were similar to the growth substrates utilized by other desulfovibrios, but even more restricted. For example, the Japan Sea isolates did not utilize ethanol, formate, or malate (Table 1). However, they did exhibit enhanced fermentation abilities and were able to ferment both lactate and pyruvate, unlike either $D$. salexigens or $D$. desulfuricans. The utilization of inorganic electron acceptors in addition to sulfate, iron oxyhydroxide, nitrate, sulfite, and thiosulfate (only strain $500-1^{\mathrm{T}}$ ) by the Japan Sea strains is similar to the utilization by other desulfovibrios. However, the ability of the Japan Sea strains to use lignosulfonate, although previously found in another sulfate-reducing bacterium (48), is in contrast to the characteristics of the Desulfovibrio type strains tested in this study (Table 1). Although not remarkable, the metabolic capabilities of the Japan Sea isolates, which exhibit enhanced fermentation, an ability to use complex organic sulfonates and ferric iron as electron acceptors, and an ability to grow on hydrogen, are characteristics that are consistent with the deep sulfate-limited environment from which they were isolated (9). Hydrogen can be produced by several deep mineral reactions $(13 a, 41 a)$.

As the Japan Sea strains are the first bacteria from very deep sediment layers to be isolated and characterized, it was important that the ability of these organisms to be active under simulated in situ conditions be established and that the maximum temperature and pressure ranges for activity be determined. As considerable bacterial activity may occur in the environment without growth, a situation that is particularly true for anaerobic bacteria (45a), sulfide production rather than growth was used to determine activity ranges. As both the Japan Sea strains and type strains of previously described desulfovibrios were grown under the same conditions, comparisons between them were valid, but the results may not be identical to the results of experiments based on growth. Sulfide production, however, was correlated with bacterial concentration $(P=0.05)$, and the experiments were reproducible and statistically significant. The pressure characteristics of the Japan Sea strains, compared to either $D$. salexigens or $D$. desulfuricans, are remarkable. Based on sulfide production, not only are the Japan Sea strains barophiles, but the optimum pressures for activity for $80-55$ and $500-1^{\mathrm{T}}$ coincided with the pressures at the total depths (water column and sediment depths) from which they were isolated (10 and $15 \mathrm{MPa}$, respectively [100 and 150 atm, respectively]) (Fig. 4). This characteristic is similar to characteristics of other barophiles (46a) and pro- 
vides strong evidence that the organisms were obtained from deep sediments. Furthermore, the Japan Sea isolates were active at pressures up to about $40 \mathrm{MPa}(400 \mathrm{~atm})$, in marked contrast to both $D$. salexigens and $D$. desulfuricans. Limited data for bacterial growth under elevated pressures confirmed that the Japan Sea strains could also grow better at elevated pressures than at $0.1 \mathrm{MPa}(1 \mathrm{~atm})$; however, overall, growth was reduced with increasing pressure more rapidly than activity.

The broad temperature profiles $\left(15\right.$ to $\left.65^{\circ} \mathrm{C}\right)(\mathrm{Fig} .2)$ of the Japan Sea isolates were also very different from the temperature profiles of other desulfovibrios, which normally are not active at temperatures above $40^{\circ} \mathrm{C}(46)$. There was considerable sulfate reduction at the extreme temperatures and there was no sharp temperature optimum, characteristics that are markedly different from the characteristics of the type strains of the previously described desulfovibrios. The thermal gradient in the Japan Sea was $111^{\circ} \mathrm{C} / \mathrm{km}$ (19), and hence the temperature characteristics of the Japan Sea isolates enable them to grow in sediments more than $500 \mathrm{~m}$ deep.

Since $D$. salexigens requires about $2 \% \mathrm{NaCl}$ for growth and is resistant to $1 \mathrm{~g}$ of hibitane per liter $(34,40)$, these characteristics were checked for the Japan Sea isolates. Both isolates required only $0.6 \% \mathrm{NaCl}$ for activity and growth and could grow at higher $\mathrm{NaCl}$ concentrations than $D$. salexigens (Fig. 3). The ability to grow at high concentrations of $\mathrm{NaCl}$ is also a characteristic of $D$. halophilus (4a); however, this sulfate-reducing bacterium requires at least $3 \% \mathrm{NaCl}$ for growth and can tolerate up to $18 \% \mathrm{NaCl}$, compared to $10 \% \mathrm{NaCl}$ for the Japan Sea strains. D. halophilus is also different from the Japan Sea strains in terms of growth substrates since it is able to use formate and ethanol for sulfate reduction but cannot ferment pyruvate. $D$. gabonensis, a recently isolated moderately halophilic desulfovibrio (42a), differs markedly from the Japan Sea isolates as it has a salinity range of 1 to $17 \%$, can grow on a much wider range of substrates, and utilizes different electron acceptors. In contrast to $D$. salexigens, hibitane concentrations as low as $0.1 \mathrm{~g} /$ liter inhibited growth of the Japan Sea isolates. The inability of the Japan Sea isolates to respire or ferment choline distinguishes them from $D$. desulfuricans. Therefore, consistent with the 16S rRNA gene sequence analysis data (Fig. 5), the phenotypic characteristics of the Japan Sea isolates are similar to, but distinct from, the phenotypic characteristics of $D$. salexigens and other desulfovibrios, and we propose a new species of the genus Desulfovibrio, Desulfovibrio profundus, for the Japan Sea isolates. D. profundus clusters with the moderately halophilic organism $D$. halophilus and the slightly halophilic organism $D$. salexigens, to which it is most closely related on the basis of $16 \mathrm{~S}$ rRNA gene analysis data.

The 16S rRNA gene sequences of strains $80-55$ and $500-1^{\mathrm{T}}$ were identical despite clear phenotypic differences between these organisms, including differences in optimum pressure for activity (Fig. 4) and some metabolic activities (Table 1). Hence, bacteria can be very closely related as determined by $16 \mathrm{~S}$ rRNA analysis but still have phenotypic differences that are environmentally important. The close relationship between the Japan Sea isolates and near-surface desulfovibrios (D. salexigens and $D$. desulfuricans), combined with the high optimum pressures of genetically identical strains $80-55$ and $500-1^{\mathrm{T}}$, which were isolated from different sediment depths ( 80 and $500 \mathrm{~m}$ below the seafloor, respectively), suggests that adaptation during burial is a possible mechanism for the origin of specialized deep-sediment bacteria. When bacterial populations originally in surface sediments become buried, they have to adapt to increased temperatures and pressures and the geochemical changes that occur during burial to survive. In addition, the results of an analysis of 16S rRNA genes ampli- fied from high-molecular-weight bacterial DNA from deep Japan Sea sediment indicated that there are other novel bacterial types present (37). Pressure tolerance and other characteristics of the Japan Sea isolates demonstrate that these bacteria are well-adapted to their deep sediment environment and hence that they are not dormant or just surviving in situ, but are an active and important component of this environment. D. profundus is the first sulfate-reducing bacteria from extreme depths in marine sediments that has been characterized. Bacterial populations deep within marine sediments represent a unique new source of bacterial diversity with potential significance for biotechnological application (for example, microbially enhanced oil recovery) (1a).

Description of Desulfovibrio profundus sp. nov. Desulfovibrio profundus (pro.fun'dus. L. adj. profundus, deep). Motile, gramnegative, desulfoviridin-positive, vibrio-shaped or sigmoid cells $(0.5$ to 1 by 1 to $2 \mu \mathrm{m})$. The following growth ranges are based on sulfide production: temperature range for growth, 15 to $65^{\circ} \mathrm{C}$ (optimum growth occurs at temperatures around $25^{\circ} \mathrm{C}$ ); $\mathrm{pH}$ range for growth, 4.5 to 9 , (optimum $\mathrm{pH}$, around 7); salinity range for growth, 0.2 to $10 \% \mathrm{NaCl}$ (optimum $\mathrm{NaCl}$ concentration, 0.6 to $8 \%$ ); pressure range, 0.1 to $40 \mathrm{MPa}$ (1 to $400 \mathrm{~atm}$ ) (optimum pressure, 10 to $15 \mathrm{MPa}$ [100 to $150 \mathrm{~atm}$ ], depending on the strain). Strict anaerobe. Reduces sulfate, sulfite, and thiosulfate (depending on the strain) to sulfide. Nitrate, ferric iron, dimethyl sulfoxide (depending on the strain), and lignosulfonate are used as alternative electron acceptors. Substrates used for dissimilatory sulfate reduction are lactate and pyruvate, which are incompletely oxidized to acetate, and hydrogen. Lactate and pyruvate are fermented in the absence of sulfate. Desulfoviridin is present. The $\mathrm{G}+\mathrm{C}$ content of the DNA is $53 \mathrm{~mol} \%$ (as determined by high-performance liquid chromatography). Isolated from deep marine sediment. The type strain is strain 500-1 (= DSM 11384).

\section{ACKNOWLEDGMENTS}

We are indebted to the Ocean Drilling Program for enabling us to obtain samples from Leg 128 and for general assistance on board the Joides Resolution. We are grateful to Steve Barnes for critical comments and general assistance, including continued subculturing of the Japan Sea isolates. We thank Gareth Riely for conducting the PLFA analysis. We gratefully acknowledge assistance from the use of the SEQNET facility at CCL, Daresbury Laboratory, the Ribosomal Database Project (University of Illinois), and the Antwerp Ribosomal Database (University of Antwerp)

This research was funded by the Natural Environment Research Council, United Kingdom.

\section{REFERENCES}

1. Ausubel, F. M., R. Brent, R. E. Kingston, D. D. Moore, J. G. Seidman, J. A Smith, and K. Struhl. 1989. Current protocols in molecular biology. Greene Publishing Associates, Wiley Interscience, New York, N.Y.

1a.Bernard, F. P., J. Connan, and M. Magot. 1992. Indigenous microorganisms in connate water of many oil fields: a new tool in exploration and production techniques, p. 467-476. In Proceedings of the 67th Annual Technical Conference and Exhibition of the Society of Petroleum Engineers.

2. Bligh, E. G., and W. J. Dyer. 1959. A rapid method of total lipid extraction and purification. Can. J. Biochem. Physiol. 35:911-917.

3. Bolliger, R., K. W. Hanselmann, and R. Bachofen. 1991. Microbial potential in deep-sea sediments. Experientia 47:517-523.

4. Canfield, D. E. 1991. Sulfate-reduction in deep sea sediments. Am. J. Sci. 291:177-188.

4a.Caumette, P., Y. Cohen, and R. Matheron. 1991. Isolation and characterisation of Desulfovibrio halophilus sp. nov., a halophilic sulfate-reducing bacterium isolated from Solar Lake (Sinai). Syst. Appl. Microbiol. 14:33-38.

5. Claypool, G., and I. R. Kaplan. 1974. The origin and distribution of methane in marine sediments, p. 99-139. In I. R. Kaplan (ed.), Natural gases in marine sediments. Plenum, New York, N.Y.

6. Cline, J. D. 1969. Spectrophotometric determination of hydrogen sulfide in natural waters. Limnol. Oceanogr. 14:454-458.

7. Cord-Ruwisch, R., W. Kleinitz, and F. Widdel. 1987. Sulfate-reducing bac- 
teria and their activities in oil production. J. Petrol. Technol. 1:97-106.

8. Cragg, B. A., S. J. Bale, and R. J. Parkes. 1992. A novel method for the transport and long-term storage of cultures and samples in an anaerobic atmosphere. Lett. Appl. Microbiol. 15:125-128.

9. Cragg, B. A., S. M. Harvey, J. C. Fry, R. A. Herbert, and R. J. Parkes. 1992 Bacterial biomass and activity in the deep sediment layers of the Japan Sea, hole 798B. Proc. Ocean Drilling Program, Scientific Results 127/128:761776

10. Cragg, B. A., R. J. Parkes, J. C. Fry, A. J. Weightman, P. A. Rochelle, and J. R. Maxwell. 1996. Bacterial populations and processes in sediments containing gas hydrates (ODP Leg 146: Cascadia Margin). Earth Planet. Sci. Lett. 139:497-507.

11. Cragg, B. A., R. J. Parkes, J. C. Fry, A. J. Weightman, J. R. Maxwell, M. Kastner, M. Hovland, M. J. Whiticar, J. C. Sample, and R. Stein. 1995 Bacterial profiles in deep sediments of the Santa Barbara Basin Site 893. Proc. Ocean Drilling Program, Scientific Results 146(Part 2):139-144.

12. Cragg, B. A., R. J. Parkes, J. C. Fry, A. J. Weightman, P. A. Rochelle, J. R. Maxwell, M. Kastner, M. Hovland, M. J. Whiticar, and J. C. Sample. 1995. The impact of fluid and gas venting on bacterial populations and processes in Cascadia margin (holes 888-892) accretionary sediments and the geochemical consequences. Proc. Ocean Drilling Program, Scientific Results 146:399-411.

13. Devereux, R., and D. A. Stahl. 1993. Phylogeny of sulfate-reducing bacteria and a perspective for analyzing their natural communities, p. 131-160. In J. M. Odom and R. Singleton (ed.), The sulfate-reducing bacteria: contemporary perspectives. Springer Verlag, New York, N.Y.

13a.Drobner, E., H. Huber, G. Wachtershauser, D. Rose, and K. O. Stetter. 1990 Pyrite formation linked with hydrogen evolution under anaerobic conditions. Nature 346:742-744.

14. Edlund, A., P. D. Nichols, R. W. Roffey, and D. C. White. 1985. Extractable and lipopolysaccharide fatty acid and hydroxy acid profiles from Desulfovibrio species. J. Lipid Res. 26:982-988.

15. Felsenstein, J. 1989. PHYLIP-phylogeny inference package (version 3.2) Cladistics 5:164-166.

16. Froelich, P. N., G. P. Klinkhammer, M. L. Bender, N. A. Luedtke, G. R. Heath, D. Cullen, P. Dauphin, D. Hammond, B. Hartman, and V. Maynard. 1979. Early oxidation of organic matter in pelagic sediments of the eastern equatorial Atlantic: suboxic diagenesis. Geochim. Cosmochim. Acta 43:1075-1090.

17. Guckert, J. B., C. P. Antworth, P. D. Nichols, and D. C. White. 1985 Phospholipid, ester-linked fatty acid profiles as reproducible assays for changes in prokaryotic community structure of estuarine sediments. FEMS Microbiol. Ecol. 31:147-158.

18. Higgins, D. G., A. J. Bleasby, and R. Fuch. 1992. CLUSTAL V: improved software for multiple sequence alignment. Comput. Applic. Biosci. 8:189-191.

19. Ingle, J. C., K. Suyehiro, M. T. von Breymann, et al. 1990. Initial reports, leg 128. Proc. Ocean Drilling Program, Scientific Results College Station, Tex

20. Jones, R. E., R. E. Beeman, and J. M. Suflita. 1989. Anaerobic metabolic processes in the deep terrestrial subsurface. Geomicrobiology 7:117-130.

21. Jørgensen, B. B. 1982. Mineralization of organic matter in the seabed-the role of sulphate reduction. Nature 296:643-645.

22. Jørgensen, B. B. 1983. Processes at the sediment-water interface, p. 477-509. In $\mathrm{B}$. Bolin and R. B. Cook (ed.), The major biogiochemical cycles and their interactions, John Wiley, Chichester, United Kingdom.

23. Krumbein, W. E. 1983. Microbial geochemistry. Blackwell, Oxford, United Kingdom

24. Laemmli, U. K. 1971. Cleavage of structural proteins during the assembly of the head of bacteriophage T4. Nature 227:680-685

25. Lane, D. J. 1991. 16S/23S rRNA sequencing, p. 115-175. In E. Stackebrand and M. Goodfellow (ed.), Nucleic acid techniques in bacterial systematics. John Wiley \& Sons, Chichester, United Kingdom.

26. Maidak, B. L., N. Larsen, M. J. McCaughey, R. Overbeek, G. J. Olsen, K. Fogel, J. Blandy, and C. R. Woese. 1994. The Ribosomal Database Project. Nucleic Acids Res. 22:3485-3487.

27. Morita, R. Y., and C. E. Zobell. 1955. Occurrence of bacteria in pelagic sediments collected during the Mid-Pacific Expedition. Deep-Sea Res. 3:66-73.

28. Morrissey, J. H. 1981. Silver stain for proteins in polyacrylamide gels: a modified procedure with enhanced uniform sensitivity. Anal. Biochem. 117:307-310

29. Neefs, J.-M., Y. Van de Peer, P. De Rijk, P. Chapelle, and R. De Wachter. 1993. Compilation of small ribosomal subunit RNA structures. Nucleic Acids Res. 21:3025-3049.

30. Parkes, R. J., B. A. Cragg, S. J. Bale, J. M. Getliff, K. Goodman, P. A. Rochelle, J. C. Fry, A. J. Weightman, and S. M. Harvey. 1994. Deep bacterial biosphere in Pacific Ocean sediments. Nature 371:410-413.

31. Parkes, R. J., B. A. Cragg, S. J. Bale, K. Goodman, and J. C. Fry. 1995. A combined ecological and physiological approach to studying sulphate reduction within deep marine sediment layers. J. Microbiol. Methods 23:235-249.

32. Parkes, R. J., B. A. Cragg, J. M. Getliff, S. M. Harvey, J. C. Fry, C. A. Lewis, and S. J. Rowland. 1993. A quantitative study of microbial decomposition of biopolymers in recent sediments from the Peru Margin Mar. Geol 113.55-66.

33. Pedersen, K., and S. Ekendahl. 1990. Distribution and activity of bacteria in deep granitic groundwaters of southeastern Sweden. Microb. Ecol. 20:37-52

34. Postgate, J. R. 1984. Genus Desulfovibrio, p. 666-672. In N. R. Krieg and J. G. Holt (ed.), Bergey's manual of systematic bacteriology, vol. 1. Williams \& Wilkins, Baltimore, Md.

35. Postgate, J. R. 1984. The sulphate-reducing bacteria, 2nd ed. Cambridge University Press, Cambridge, United Kingdom.

36. Rheinheimer, G. 1985. Aquatic microbiology. John Wiley \& Sons, Chichester, United Kingdom.

37. Rochelle, P. A., J. C. Fry, A. J. Weightman, R. J. Parkes, and B. A. Cragg 1994. Evaluation of genetic diversity of bacteria in marine sediments up to 3 million years old by direct and indirect 16S rRNA gene sequence analysis, p. 53-57. Lyell Meeting Volume. Special publication 94/1. NERC Earth Sciences Directorate, Swindon, United Kingdom.

38. Rochelle, P. A., J. A. K. Will, J. C. Fry, G. J. S. Jenkins, R. J. Parkes, C. M. Turley, and A. J. Weightman. 1995. Extraction and amplification of $16 \mathrm{~S}$ rRNA genes from deep marine sediments and seawater to assess bacterial community diversity, p. 219-239. In J. D. van Elsas and J. T. Trevors (ed.) Nucleic acids in the environment: methods and applications. Springer-Verlag, Berlin, Germany.

39. Sambrook, J., E. F. Fritsch, and T. Maniatis. 1989. Molecular cloning: a laboratory manual, 2nd ed. Cold Spring Harbor Press, Cold Spring Harbor, N.Y.

40. Skyring, G. W., H. E. Jones, and D. Goodchild. 1977. The taxonomy of some new isolates of dissimilatory sulfate-reducing bacteria. Can. J. Microbiol. 23 1415-1425.

41. Stetter, K. O., R. Huber, E. Blochl, M. Kurr, R. D. Eden, M. Fielder, H. Cash, and I. Vance. 1993. Hyperthermophilic archaea are thriving in deep North Sea and Alaskan oil reservoirs. Nature 365:743-745.

41a.Stevens, T. O., and J. P. McKinley. 1995. Lithoautotrophic microbial ecosystems in deep basalt aquifers. Science 270:450-454

42. Tamaoka, J., and K. Komagata. 1984. Determination of DNA base composition by reversed-phase high-performance liquid chromatography. FEMS Microbiol. Lett. 25:125-128.

42a.Tardy-Jacquenod, C., M. Magot, F. Laigret, M. Kaghad, B. K. C. Patel, J. Guezennec, R. Metheron, and P. Caumette. 1996. Desulfovibrio gabonensis sp. nov., a new moderately halophilic sulfate-reducing bacterium isolated from an oil pipeline. Int. J. Syst. Bacteriol. 46:710-715.

43. Taylor, J., and R. J. Parkes. 1983. The cellular fatty acids of the sulphatereducing bacteria Desulfobacter $\mathrm{sp}$., Desulfobulbus sp. and Desulfovibrio de sulfuricans. J. Gen. Microbiol. 129:3303-3309.

44. van de Peer, Y., and R. de Wachter. 1994. TREECON for Windows: software package for the construction and drawing of evolutionary trees for the Microsoft Windows environment. Comput. Applic. Biosci. 10:569-570.

45. Wellsbury, P., R. A. Herbert, and R. J. Parkes. 1994. Bacterial [methyl$3 \mathrm{H}$ |thymidine incorporation in substrate-amended estuarine sediment slurries. FEMS Microbiol. Ecol. 15:237-248.

45a.Wellsbury, P., R. A. Herbert, and R. J. Parkes. 1996. Bacterial activity and production in near-surface estuarine and freshwater sediments. FEMS Microbiol. Ecol. 19:203-214

46. Widdel, F., and F. Bak. 1991. Gram-negative mesophilic sulphate-reducing bacteria, p. 3352-3378. In A. Balows, H. G. Trüper, M. Dworkin, W. Harder, and K. H. Schleifer (ed.), The prokaryotes, 2 nd ed. Springer-Verlag, New York, N.Y.

46a.Yayanos, A. A., A. S. Dietz, and R. van Boxtel. 1982. Dependence of repro duction rate on pressure as a hallmark of deep-sea bacteria. Appl. Environ. Microbiol. 44:1356-1361.

47. Yruela, I., A. Barbe, and J. O. Grimalt. 1990. Determination of double bond position and geometry in linear and higly branched hydrocarbons and fatty acids from gas chromatography-mass spectrometry of epoxides and diols generated by stereospecific resin hydration. J. Chromatogr. Sci. 28:421-427.

48. Ziomek, E., and R. E. Williams. 1989. Modification of lignins by growin cells of the sulfate-reducing anaerobe Desulfovibrio desulfuricans. Appl. Environ. Microbiol. 55:2262-2266.

49. Zobell, C. E. 1938. Studies on the bacterial flora of marine bottom sediments J. Sediment Petrol. 8:10-18 